\title{
Self-perceived employability attributes of adult learners within an open distance learning environment
}

\section{BEZUIDENHOUT*}

Department of Human Resource Management, University of South Africa bezuiml@unisa.ac.za

* corresponding author

\section{EC RUDOLPH}

Department of Human Resource Management, University of South Africa rudolec@unisa.ac.za

\author{
AM FURTAK \\ Department of Human Resource Management, University of South Africa \\ hyraam@unisa.ac.za
}

\begin{abstract}
This study examined the employability self-perceptions of South African open distance learning (ODL) higher education students. Although studies have been conducted within an ODL environment on graduates' employability, rising unemployment together with a lack of industry-specific skills requires more investigation into the concept of employability. It is therefore envisaged that this study will provide valuable information in this regard and add to the current body of knowledge on employability. The employability attributes scale (EAS) was administered to a target population of $N=1706$ ODL students (second to fourth year) in the economic and management sciences field. A quantitative, cross-sectional research design approach was used. The data were analysed to determine students' demographic effects on self-perceived employability. Results suggest that white and younger students perceive themselves as more employable than other ethnic groups by age groupings. Results may reflect historical opportunity structure effects on employability in a modern South African economy. The findings provide valuable information that organisations can use for career development support and counselling practices in the contemporary world of work. They further provide important insights informing human resource practices aimed at addressing the career needs of different age and race groups. The implications of this study will be helpful in guiding both industry and academia in incorporating and enhancing these skills among professionals.
\end{abstract}

Journal of Contemporary Management

DHET accredited

ISSN 1815-7440
Volume 16

2019

Pages 106-139
Page 1 


\section{Key phrases}

Adult learners; employability; higher education and open distance learning

\section{INTRODUCTION}

Employer perceptions about the quality of graduates from higher education institutions (HEI) influence the graduands' perceived employability or general work readiness (Coetzee 2012:119-52). Due to South Africas' slow and shaky economy and high and increasing levels of unemployment, particularly among the countries' youth, many graduates find it virtually impossible to find a suitable place in the labour market (Paadi 2014:129).

In the multicultural South African context, it would appear valuable to gain an understanding of the employability attributes of adult learners, as it could bring new awareness to the design of formal learning and development programmes and help to promote the continued employability of adult learners attending these programmes (Coetzee \& Potgieter 2014). Historically, those with open and distance learning were perceived as less well prepared for work settings than those with on-campus instruction (Attri 2012), although such perceptions are changing with the wider adoption of open and distance learning options buttressed with online instructions, as with massive open distance learning courses (Botha, Coetzee \& Coetzee 2015). The idea that a degree is a "passport to employment" has been relegated to the past (Harvey 2000:7). Gradually, even an excellent degree cannot guarantee a student a graduate-level job. The development and awareness of ones' employability skills is progressively seen as a way of improving ones' career opportunities and increasing academic performance (Baker \& Henson 2010). Even though it is not expected of HEls to produce fully-fledged practitioners/employees, the set of knowledge, skills and competence at entry-level employability is the first crucial step to further development and to lifelong employability (Świgoǹ 2016:3610). In addition, in the current economic climate, an important

Journal of Contemporary Management

DHET accredited

ISSN 1815-7440
Volume 16

2019

Pages 106-139
Page 2 
role of academia is to support students and graduates in developing the necessary qualities, behaviours, skills and competencies for the modern workplace (Świgoǹ 2016).

\section{PROBLEM STATEMENT}

According to Tumuti, Mule, Gecaga and Manguriu (2013), recent literature on the relationship between $\mathrm{HEI}$ and graduate employment has emphasised that universities need to develop a deep understanding of the graduate attributes required in the labour market. Tumuti et al. (2013) suggest that generic skills require more attention from HEls.

Barthorpe and Hall (2000) recommend that employers search for new graduates that can immediately become involved in delivering value to the company, without having to make use of lengthy induction programmes. Expectations such as these, therefore, call for graduates to display qualities that will empower them to "hit the ground running" and keep abreast with the latest developments in a changing work environment (Bezuidenhout 2011:2). Even though studies are conducted to investigate students' employability attributes, there remains a gap in the literature in terms of the understanding of employability skills of graduates. To this effect, the attributes needed to make graduates employable in the new world of work still require more investigation.

A study by De Guzman and Choi (2013:200) focused on individuals' adaptability resources in terms of self-regulation strategies or strengths that enable individuals to broaden, refine and eventually direct their adaptive behaviours to create a concept of whether they are employable. Botha (2014:1.3) suggests that the dichotomous situation facing South Africa that of rising graduate unemployment (Pauw, Oosthuizen \& Van der Westhuizen 2008), together with a lack of industry-specific skills - requires further investigation into the concept of employability. The researchers' main assumption, that graduands' employment readiness remains an open question, was the drive to initiate in three modules a survey to determine the needs of students regarding employability and ongoing learning within an ODL 
environment. Subsequently, the researchers asked whether there is a difference between ODL students' self-perceived employability attributes in terms of age, gender, ethnicity/race and education level.

Employers promote employees showing evidence of continuous work and relevant learning, and offer additional incentive pay to enhance ongoing learning (Bussin 2012). In South Africa, there is an ongoing debate regarding the preparedness of graduates for the world of work. Since the future workforce will be comprised of students, there is a need to continuously investigate the employability of students (Koloba 2015). It is therefore envisaged that this study will provide valuable information in this regard and add to the current body of knowledge on employability. Considering the fact that graduate employability is placed on the ODLs' agenda, and that a lack of employability skills makes it difficult for employees to adapt to their work demands (Biemann, Zacher \& Feldman 2012), this study seems timely and important.

\section{RESEARCH OBJECTIVES AND QUESTIONS}

The primary objective of this study is to determine the employability attributes and the role of demographic variables such as age, gender, race/ethnicity and education levels of adult learners. This study sought to address the following research question: How do working students within an ODL environment self-perceive their employability, taking into account their socio-demographics of age, ethnicity, gender, and qualifications level? Findings from this study will contribute to the literature by providing evidence of the factors identified to be of importance in self-perceived employability of students. This study is also relevant due to its contribution of empirical evidence that extends current conceptualisation in the area of self-perceived employability of students. 


\section{LITERATURE REVIEW}

Self-perceived employability can be defined as the ability to keep the job one has or to get the job one desires (Świgon 2016:3610). According to Clarke (2008:262) and from an individual perspective, self-perceived employability may be understood "in terms of skills and abilities, attitudes and behaviours, as a current state, a process or a future outcome, and individual characteristic made up of the sum of an individual's job-related skills, or as a reflection of the individual's position within the labour market". Next follows a brief description of the different factors that influence scholars' thinking related to the area of selfperceived employability, such as work readiness, an attributes framework, contemporary management, higher education and the influence of country settings.

\subsection{Employability and work readiness}

Employability refers to "work readiness", that is, possession of the skills, knowledge, attitudes and commercial understanding for employment (Mason, Williams, Cranmer \& Guile 2003). Olivier (2015) maintains that the most widely accepted definition of employability was put forward by Yorke (2006:8), namely: "Employability means that students acquire the skills, understanding and personal attributes that make them more likely to secure employment and be successful in their chosen occupations to the benefit of themselves, the workforce and the community and the economy". Stokes (2013) defines employability as an individuals' long-term capacity to build a career and to prosper in a labour market. Jackson (2014) maintains that employability is a persons' ability to conceptualise tasks, and develop expertise and behaviour that improve performance within any work environment. Bezuidenhout (2011:20) defines employability as a "psycho-social construct representing a combination of attributes (dispositions, values, attitudes and skills) that promote proactive adaptability in changing environments and enhance an individual's suitability for employment and the likelihood of obtaining career success". Bennett (2016:6) defines ability as "the ability to find, create and sustain meaningful work across the career lifespan". Even though

Journal of Contemporary Management

DHET accredited

ISSN 1815-7440
Volume 16

2019

Pages 106-139
Page 5 
definitions of employability are diverse, it can be seen as a blend of understanding, skilful practices, efficacy beliefs and reflectiveness (Little 2006) and the capability of people having the confidence in their ability to take effective and appropriate action and to continue to learn from their experiences (Olivier 2015).

While the concept of employability is not a new idea (Bezuidenhout 2011), its focus and weight are changing (Stokes 2013). Emphasis is now being placed on how prepared individuals are for changes taking place in the economy and the world of work, such as expansion, job creation and increased job insecurity (Stokes 2013). In addition, the criteria used to evaluate employability are also changing. Potential workers need to be trainable to be employable.

Today, employability suggests that individuals must demonstrate their initiative and adaptability to learn continuously, not only to attain employment, but also to be promotable or retain their job (Stokes 2013:1). Individuals with a self-directed career attitude experience greater responsibility for their career choices and opportunities and are more enthusiastically involved with their career development (Briscoe, Hall \& DeMuth 2006; Sullivan \& Baruch 2009). Employees therefore need to be self-directed and lifelong learners to remain employable (Stokes 2013). Briscoe and Hall (2006:8) define self-directedness as the "ability to be adaptive in terms of performance and learning demands".

The employability qualities employers impute on university graduands may depend on the institutions that the graduands attended (Lourens \& Fourie-Malherbe 2016) as well as the mode of instruction they completed (Bennett 2016; Fry, Ketteridge \& Marshall 2009).

\subsection{Employability attributes framework}

The employability attributes framework (EAF) developed by Bezuidenhout (2011) in collaboration with Coetzee (2010) is of significance to the present study. The EAF has specifically been designed for students in the South African higher education context. This

Journal of Contemporary Management

DHET accredited

ISSN 1815-7440
Volume 16

2019

Pages 106-139
Page 6 
framework describes a set of eight core employability attributes that are regarded as important for increasing the likelihood of securing and sustaining employment opportunities (Bezuidenhout 2011). The EAF focuses on attributes that may be developed in the higher education setting by creating an environment that is conductive to the cultivation of these attributes. The EAF consists of the following eight measures: career self-management, cultural competence, career resilience, proactivity, entrepreneurial orientation, sociability, self-efficacy and emotional literacy.

Career self-management refers to the individual capacity to ensure continued employability by developing an ongoing learning orientation and autonomously planning and managing a career (Bezuidenhout \& Coetzee 2010; Botha 2014; Coetzee 2012). Career resilience involves an individuals' ability to adapt to changing situations by accepting job and organisational changes, looking forward to working with different and new people, being willing to take risks as well as having self-confidence (Schreuder \& Coetzee 2011). An entrepreneurial orientation entails viewing risks and potential opportunities, a tolerance for ambiguity, a preference for innovation, creativity and autonomous action in the career progression (Bezuidenhout \& Coetzee 2010; Botha 2014; Coetzee 2012). Proactivity is the ability of the individual to be an active agent in career planning and management (Bezuidenhout \& Coetzee 2010; Botha 2014; Coetzee 2012). Self-efficacy consists of the ability to function independently of others, to make ones' own decisions, to have the confidence to accomplish ones' goals through ones' own effort, to persist with challenges and to enjoy the discovery of original solutions (Bezuidenhout 2011). Cultural competence involves knowing the customs of other cultures, understanding their values and beliefs and being able to initiate and maintain relationships with people from diverse cultural backgrounds (Bezuidenhout 2011). Cultural competence is especially critical in a diverse employment context such as the South African workplace (Ndzube 2013). Emotional literacy refers to the awareness of and the capacity to change and manage personal emotions as 
well as the feelings of others (Bezuidenhout \& Coetzee 2010; Botha 2014; Coetzee 2012). Sociability is the skill to network with and build social contacts (Coetzee \& Potgieter 2014).

\subsection{Employability and contemporary management}

The speed and nature of globalisation, technological change and innovation, changes in work organisations, environmental change and demographic trends take different forms across organisations. Increasing the employability of the workforce in the face of ongoing and future structural changes can help foster innovation and adoption of new technologies as well as boost productivity (Organisation for Economic Co-operation and Development (OECD) 2016:3).

\subsection{Higher education and employability}

Higher education (HE) today is tasked with developing employability in their adult learners in order to increase the productive potential of the human resources of organisations (Boden \& Nedeva 2010; Coetzee 2012). Despite this, the concept of employability is both unclear and indefinite (Botha 2014:3.1).

A common theme across higher education policy and funding throughout the world is the need to ensure that graduates are prepared for and able to contribute to the economy and society. Employability is therefore labelled as one of the most significant challenges facing contemporary HE (Moolman 2013). In fact, Baker and Henson (2010) argue that the provision of opportunities for the development of employability skills and career awareness has become central in debates about the future of HE. Prokou (2008) proposes that it is accepted that HE has a responsibility for advancing employability of graduates in developing the abilities and skills of students and promoting lifelong learning.

For part-time degree students who are already working, the concept of employability is likely to be linked to issues of confidence and self-esteem (Little 2011) as well as career development and access to the professions (Pegg, Waldock, Hendy-Isaac \& Lawton 2012).

Journal of Contemporary Management

DHET accredited

ISSN 1815-7440
Volume 16

2019

Pages 106-139
Page 8 
These authors furthermore suggest that some employers, and many students, continue to value the broadest understanding of employability and HE learning in developing their professional identities.

Pegg et al. (2012:8) posit that HE should enhance the employment potential for the full spectrum of its graduates and acknowledge the different economic forces that influence the graduates' success. However, continuing the assumption that students can all be treated the same way, and have equal confidence in dealing with the labour market, runs the risk of maintaining disadvantage, as the relatively advantaged are able to maintain their positions.

\subsection{Influence of country setting context}

The assumption that all open and distance learning students with similar continuing learning opportunities would perceive themselves as being equally employable, runs the risk of maintaining disadvantage, as the historically relatively advantaged may have higher actual employability. In the South African setting, socio-demographics of race/ethnicity, gender and age [i.e. Generations $X$ (age range 18-32) and $Y$ (age range 33-52)] may influence selfperceptions of employability, since existing definitions of employability suggest that individual characteristics determine employability (Clarke 2008). In addition, these characteristics are often critical in determining a persons' "ability to keep the job one has or to get the job one desires" (Hillage \& Pollard 1998:2). In a study conducted by Moreau and Leathwood (2006), age was seen to have influenced outcomes, with more mature graduates attracting more attention in the labour market than the younger ones.

According to McGuigan (2010), various studies have indicated that perceptions of employability and employability attributes differ with age. Nielsen (1999) found perceptions of employability to differ with age. Compared to individuals aged 18 to 34 years, those aged 34 to 44 years were $1.7 \%$ more likely to have negative perceptions of employability, whilst those aged 44 and above were $3.0 \%$ more likely to have negative perceptions of 
employability. Rothwell and Arnold (2007) also found perceptions of employability to differ with age; those younger than 34 years held higher perceptions of employability and those aged 55 years and older showed lower perceptions of employability. Van Rooy, Alonso and Viswesvaran (2005) found a positive relationship between age and employability. Generation, in this study, is directly derived from age, hence the discussion following the different generations.

McGuigan (2010) postulates that popular psychology literature suggests that members of Generation $X$ and $Y$ may have higher perceptions of employability than Baby Boomers. Compared to Baby Boomers, individuals in Generations $X$ and $Y$ are viewed as individuals who require more feedback (Hankin 2005), spend less time in a position and have less commitment to an organisation (Cennamo \& Gardner 2008; Kupperschmidt 2000). According to, for example, Van der Heijden (2000), these factors are related to increased perceptions of employability. In addition, Generation $\mathrm{Y}$ is more adaptable and optimistic than Generation X and Baby Boomers, making them more inwardly focused on their careers (McGuigan 2010). This could increase Generation Ys' perceptions of employability (Sheahan 2005). McGuigan (2010) found that Baby Boomers' perceptions of their employability were significantly lower than those of individuals from Generations $X$ and $Y$.

Coetzee and Schreuder (2008) highlighted the importance of research in light of the multicultural South African work environment. Organisations need to consider the differences or similarities between generations, as they might also be different in terms of their values, expectations, needs, workplace practices, and personalities on individual or group level, which in turn could result in conflicting preferences (Bejtkovský 2016; Jonck, Van der Walt \& Sobayeni 2017). Findings from Croucher, Ramakrishnan, Rizov and Benzinger (2018:124) demonstrate a limited significance of race/ethnicity to perceived employability. Rothwell, Jewell and Hardie (2009) found no significant differences between self-perceived employability and ethnicity. However, the extent to which these historical influences apply to 
already employed students taking open and distance learning courses to increase their work competencies is in need of study.

With regard to educational level, Koloba (2015) found no statistical difference in terms of level of study and perceived employability. However, Karli (2016) found that level of education plays a significant role in participants' employability perceptions. Thindwa (2016) found that educational attainment is one of the key factors in employability. This is not surprising in view of literature supporting educational attainment as important in employability. Thindwa cautions that the relationship between education and employability is complex, since education needs to go hand in hand with courses that are demanded by the labour market.

\section{RESEARCH METHODOLOGY}

\subsection{Research design and approach}

The study aimed to determine the employability attributes and the role of demographic variables such as age, gender, race/ethnicity and education levels of adult learners. Although being a descriptive study, within this, a quantitative research method was employed. A cross-sectional study design was used to collect primary data (Zikmund, Babin, Carr, Carr \& Griffin 2013), involving adult learners enrolled for undergraduate studies in the economic and management science field at an ODL university.

\subsection{Participants and setting}

The target population in this study was $N=1706$ ODL students in the economic and management sciences field. Study participants formed a convenience sample of $725 \mathrm{ODL}$ students $($ females $=70.2 \%$; blacks $=16.5 \%$, Indian $=13.9 \%$, coloured $=3.5 \%$ and white $=$ $6.8 \%$ ), age range 20 to 61 ; (mean age $=32.86$ years; $S D=8.23$ years). By generation, $52 \%$ were Generation Y (aged between 20 and 32), 45.9\% Generation X (aged between 33 and 
52) and 1.5\% Baby Boomers (aged 53 years and above). Because there were only 11 students (1.5\%) from the Baby Boomers generation, they were excluded from the analysis.

In terms of their highest education level, the majority $(n=425 ; 58.5 \%)$ had an undergraduate degree/diploma qualification. A majority of the sample was either full- or part-time employed (81.7\%), $1.2 \%$ self-employed, with only $16.1 \%$ being unemployed.

\subsection{Research instrument}

The students completed the Employability Attributes Scale (Bezuidenhout \& Coetzee 2010), which is a 56 -item measure of eight dimensions of career self-management (11 items), cultural competence (5 items); self-efficacy (6 items), career resilience (6 items), sociability (7 items) and emotional literacy (7 items). Items are rated on a six-point Likert-type scale. A high score would suggest that the respondent was satisfied with the particular item, while a low score would indicate the opposite. Previous studies reported reliability coefficients of between 0.78 and 0.90 for scores from the EAS (Coetzee 2010; Coetzee \& Potgieter 2014). For this study, the Cronbach's alpha coefficients of 0.72 to 0.83 were observed for scores from the EAS.

\subsection{Research procedure}

Permission for the study was granted by the ODL University. The students individually consented to the study in writing. They were assured of privacy, anonymity and confidentiality of responses in the form of a participant information sheet. An electronic survey was created on e-survey creator (which created a dedicated uniform reference locator [URL] on its file server) and a message was posted on the university's student portal with a hyperlink to the URL where the survey was hosted. Students were informed in the research participant information sheet that the researchers valued their voluntary participation in the study and that they would not be penalised if they did not complete the questionnaire. Since responses were entered by means of an electronic survey, participation 
was anonymous, as students could not be identified. Only the researchers had access to the data on the URL, which was password protected.

\subsection{Statistical analysis}

Data were analysed by employability attributes and students' demographics applying the independent t-test, Mann-Whitney test, Kruskal-Wallis test and ANOVA. A t-test for independent groups was used to determine whether statistically significant differences existed between (i) the two age groups (generation $X$ and $Y$ ) and (ii) gender with regard to each of the employability attributes. A $5 \%$ level of significance was used. The null hypothesis of equal variances assumed was not rejected $(p>0.05)$ for 10 of the 11 attributes and we can thus assume equal variances. For the attribute innovation, the null hypothesis of equal variance assumed was rejected ( $p<0.05)$; therefore equal variance not assumed was used, necessitating use of non-parametric techniques for the data analysis. An independentsample t-test was also conducted to compare employability attributes between the different genders. The null hypothesis of equal variances assumed was not rejected $(p>0.05)$ for 10 of the 11 attributes and we can thus assume equal variances. For the attribute reflection, the null hypothesis of equal variance assumed was rejected $(p<0.05)$, therefore equal variance not assumed were used. Thus, to the extent that equal variances could be assumed, analysis of variance (ANOVA) procedures were utilised for the data analysis.

\subsection{Ethical considerations}

The research conformed to all academic research etiquette and ethics as described by the research and innovation policy and the policy on research ethics by the ODL University. The actual results of the study were analysed and presented without distorting any information; no deliberate or intentional misrepresentation of the results took place. The identity of the participants was protected and was not revealed during or after the study and all rights to 
privacy were protected. The data collection was treated in confidence and was not shared in a way that would bring harm to any of the participants.

\section{RESULTS}

\subsection{Empirical results}

The factor analysis results, reliability results and the results containing the research goals are discussed in this section.

\subsubsection{Factor analysis results}

The factors identified in the exploratory factor analysis (EFA) by Potgieter and Coetzee (2013) were subjected to a confirmatory factor analysis. Data for this study did not provide an acceptable fit for the model as suggested $(\mathrm{CFI}=0.611$; IFI $=0.614$; RMSEA $=0.082$ ). Subsequently, an exploratory factor analysis was conducted using principal component extraction and varimax rotation. The Kaiser-Meyer-Olkin measure of sampling adequacy $(0.943)$ and the Bartlett's test of sphericity were significant $(p=0.000)$. Both indicated that a factor analysis was appropriate. The analysis identified twelve factors, based on the eigenvalue criterion (final factor loadings are shown in Table 1) which explains $62.85 \%$ of the variance.

Table 1: Factor loadings

\begin{tabular}{|c|c|c|c|c|c|c|c|c|c|c|c|c|c|}
\hline \multirow{2}{*}{\multicolumn{2}{|c|}{$\begin{array}{c}\text { Statement and statement } \\
\text { number }\end{array}$}} & \multicolumn{12}{|c|}{ Factor } \\
\hline & & 1 & 2 & 3 & 4 & 5 & 6 & 7 & 8 & 9 & 10 & 11 & 12 \\
\hline 31 & $\begin{array}{l}\text { I can easily } \\
\text { understand why I feel } \\
\text { a certain way. }\end{array}$ & 0.73 & & & & & & & & & & & \\
\hline 29 & $\begin{array}{l}\text { I generally know what } \\
\text { emotions I am feeling. }\end{array}$ & 0.72 & & & & & & & & & & & \\
\hline 32 & $\begin{array}{l}\text { I know what to do to } \\
\text { be in a good mood. }\end{array}$ & 0.67 & & & & & & & & & & & \\
\hline 28 & It is easy for me to & 0.55 & & & & & & & & & & & \\
\hline
\end{tabular}

Journal of Contemporary Management DHET accredited ISSN 1815-7440
Volume 16

2019

Pages 106-139
Page 14 


\begin{tabular}{|c|c|c|c|c|c|c|c|c|c|c|c|c|c|}
\hline \multirow{2}{*}{\multicolumn{2}{|c|}{$\begin{array}{c}\text { Statement and statement } \\
\text { number }\end{array}$}} & \multicolumn{12}{|c|}{ Factor } \\
\hline & & 1 & 2 & 3 & 4 & 5 & 6 & 7 & 8 & 9 & 10 & 11 & 12 \\
\hline & $\begin{array}{l}\text { identify the emotions } \\
\text { of others. }\end{array}$ & & & & & & & & & & & & \\
\hline 30 & $\begin{array}{l}\text { When I am in a good } \\
\text { mood, I am better } \\
\text { able to persist with } \\
\text { challenges. }\end{array}$ & 0.55 & & & & & & & & & & & \\
\hline 34 & $\begin{array}{l}\text { I know how to control } \\
\text { my own emotions. }\end{array}$ & 0.54 & & & & & & & & & & & \\
\hline 35 & $\begin{array}{l}\text { I find it easy to disarm } \\
\text { an emotionally } \\
\text { explosive situation. }\end{array}$ & 0.50 & & & & & & & & & & & \\
\hline 33 & $\begin{array}{l}\text { I find it easy to cheer } \\
\text { someone up who is } \\
\text { sad. }\end{array}$ & 0.48 & & & & & & & & & & & \\
\hline 47 & $\begin{array}{l}\text { I am able to adapt to } \\
\text { chaining } \\
\text { circumstances in my } \\
\text { career. }\end{array}$ & & 0.70 & & & & & & & & & & \\
\hline 46 & $\begin{array}{l}\text { I anticipate and take } \\
\text { advantage of changes } \\
\text { in my career. }\end{array}$ & & 0.67 & & & & & & & & & & \\
\hline 45 & $\begin{array}{l}\text { I adapt easily to } \\
\text { changes in my } \\
\text { environment. }\end{array}$ & & 0.63 & & & & & & & & & & \\
\hline 48 & $\begin{array}{l}\text { I am able to } \\
\text { persevere even in the } \\
\text { face of difficult career } \\
\text { circumstances. }\end{array}$ & & 0.58 & & & & & & & & & & \\
\hline 41 & $\begin{array}{l}\text { I enjoy working } \\
\text { independently to } \\
\text { reach my goals. }\end{array}$ & & 0.50 & & & & & & & & & & \\
\hline 40 & $\begin{array}{l}\text { I generally set } \\
\text { challenging targets for } \\
\text { myself. }\end{array}$ & & 0.49 & & & & & & & & & & \\
\hline 44 & $\begin{array}{l}\text { I continuously look } \\
\text { into new business } \\
\text { opportunities. }\end{array}$ & & 0.40 & & & & & & & & & & \\
\hline 52 & $\begin{array}{l}\text { I pay a great deal of } \\
\text { attention to develop } \\
\text { myself. }\end{array}$ & & & 0.67 & & & & & & & & & \\
\hline
\end{tabular}

Journal of Contemporary Management

DHET accredited

ISSN 1815-7440
Volume 16

2019

Pages 106-139
Page 15 


\begin{tabular}{|c|c|c|c|c|c|c|c|c|c|c|c|c|c|}
\hline \multirow{2}{*}{\multicolumn{2}{|c|}{$\begin{array}{c}\text { Statement and statement } \\
\text { number }\end{array}$}} & \multicolumn{12}{|c|}{ Factor } \\
\hline & & 1 & 2 & 3 & 4 & 5 & 6 & 7 & 8 & 9 & 10 & 11 & 12 \\
\hline 55 & $\begin{array}{l}\text { I feel changes at work } \\
\text { or in my studies have } \\
\text { positive implications. }\end{array}$ & & & 0.63 & & & & & & & & & \\
\hline 51 & $\begin{array}{l}\text { I continuously seek } \\
\text { out improved ways of } \\
\text { doing things. }\end{array}$ & & & 0.60 & & & & & & & & & \\
\hline 53 & $\begin{array}{l}\text { I regularly keep up } \\
\text { with the latest } \\
\text { developments } \\
\text { concerning my type of } \\
\text { job or career. }\end{array}$ & & & 0.56 & & & & & & & & & \\
\hline 56 & $\begin{array}{l}\text { I am generally willing } \\
\text { to consider new } \\
\text { ideas. }\end{array}$ & & & 0.56 & & & & & & & & & \\
\hline 50 & $\begin{array}{l}\text { I spend a lot of time } \\
\text { enhancing my } \\
\text { knowledge and skills } \\
\text { to benefit my career. }\end{array}$ & & & 0.53 & & & & & & & & & \\
\hline 54 & $\begin{array}{l}\text { I am curious about } \\
\text { new things. }\end{array}$ & & & 0.47 & & & & & & & & & \\
\hline 15 & $\begin{array}{l}\text { I understand the } \\
\text { values and beliefs of } \\
\text { other cultures. }\end{array}$ & & & & 0.83 & & & & & & & & \\
\hline 14 & $\begin{array}{l}\text { I am confident in my } \\
\text { ability to communicate } \\
\text { inter-culturally. }\end{array}$ & & & & 0.72 & & & & & & & & \\
\hline 13 & $\begin{array}{l}\text { I know the customs of } \\
\text { other cultures. }\end{array}$ & & & & 0.70 & & & & & & & & \\
\hline 16 & $\begin{array}{l}\text { I can easily initiate } \\
\text { and maintain } \\
\text { relationships with } \\
\text { people from different } \\
\text { cultures. }\end{array}$ & & & & 0.67 & & & & & & & & \\
\hline 17 & $\begin{array}{l}\text { I enjoy working with } \\
\text { people from different } \\
\text { cultures. }\end{array}$ & & & & 0.60 & & & & & & & & \\
\hline 18 & $\begin{array}{l}\text { I change my non- } \\
\text { verbal behaviour in } \\
\text { different cultural } \\
\text { circumstances. }\end{array}$ & & & & 0.48 & & & & & & & & \\
\hline
\end{tabular}

Journal of Contemporary Management

DHET accredited

ISSN 1815-7440
Volume 16

2019

Pages 106-139 


\begin{tabular}{|c|l|l|l|l|l|l|l|l|l|l|l|l|}
\hline \multicolumn{2}{|c|}{$\begin{array}{l}\text { Statement and statement } \\
\text { number }\end{array}$} \\
\cline { 2 - 13 }
\end{tabular}

Journal of Contemporary Management

DHET accredited

ISSN 1815-7440
Volume 16

2019

Pages 106-139 


\begin{tabular}{|c|c|c|c|c|c|c|c|c|c|c|c|c|c|}
\hline \multirow{2}{*}{\multicolumn{2}{|c|}{$\begin{array}{c}\text { Statement and statement } \\
\text { number }\end{array}$}} & \multicolumn{12}{|c|}{ Factor } \\
\hline & & \multirow[t]{2}{*}{1} & \multirow[t]{2}{*}{2} & \multirow[t]{2}{*}{3} & \multirow[t]{2}{*}{4} & \multirow[t]{2}{*}{5} & \multirow[t]{2}{*}{6} & \multirow[t]{2}{*}{7} & \multirow[t]{2}{*}{8} & \multirow[t]{2}{*}{9} & \multirow[t]{2}{*}{10} & \multirow[t]{2}{*}{11} & \multirow[t]{2}{*}{12} \\
\hline & in my career. & & & & & & & & & & & & \\
\hline 8 & $\begin{array}{l}\text { I know what I want to } \\
\text { accomplish in my } \\
\text { career. }\end{array}$ & & & & & & & 0.59 & & & & & \\
\hline 6 & $\begin{array}{l}\text { I have clearly } \\
\text { formulated career } \\
\text { goals and action } \\
\text { plans on how to } \\
\text { achieve them. }\end{array}$ & & & & & & & 0.58 & & & & & \\
\hline 1 & $\begin{array}{l}\text { I regularly reflect on } \\
\text { what my career } \\
\text { aspirations are. }\end{array}$ & & & & & & & 0.50 & & & & & \\
\hline 5 & $\begin{array}{l}\text { I actively seek } \\
\text { feedback from others } \\
\text { to make progress in } \\
\text { my career. }\end{array}$ & & & & & & & & 0.81 & & & & \\
\hline 4 & $\begin{array}{l}\text { I regularly ask others' } \\
\text { opinions regarding my } \\
\text { strengths and } \\
\text { weaknesses. }\end{array}$ & & & & & & & & 0.79 & & & & \\
\hline 3 & $\begin{array}{l}\text { I regularly seek } \\
\text { information regarding } \\
\text { what a specific career } \\
\text { involves. }\end{array}$ & & & & & & & & 0.58 & & & & \\
\hline 10 & $\begin{array}{l}\text { I find it easy to adapt } \\
\text { to different social } \\
\text { situations. }\end{array}$ & & & & & & & & & 0.71 & & & \\
\hline 9 & $\begin{array}{l}\text { I can easily establish } \\
\text { and maintain } \\
\text { interpersonal } \\
\text { relations. }\end{array}$ & & & & & & & & & 0.64 & & & \\
\hline 21 & $\begin{array}{l}\text { I have many good } \\
\text { qualities. }\end{array}$ & & & & & & & & & & 0.71 & & \\
\hline 22 & $\begin{array}{l}\text { I take responsibility } \\
\text { for my decisions. }\end{array}$ & & & & & & & & & & 0.53 & & \\
\hline 23 & $\begin{array}{l}\text { I am responsible for } \\
\text { my own successes } \\
\text { and failures in my } \\
\text { career. }\end{array}$ & & & & & & & & & & 0.46 & & \\
\hline 12 & I can use my & & & & & & & & & & & 0.64 & \\
\hline
\end{tabular}

Journal of Contemporary Management

DHET accredited

ISSN 1815-7440
Volume 16

2019

Pages 106-139 


\begin{tabular}{|c|c|c|c|c|c|c|c|c|c|c|c|c|c|}
\hline \multirow{2}{*}{\multicolumn{2}{|c|}{$\begin{array}{c}\text { Statement and statement } \\
\text { number }\end{array}$}} & \multicolumn{12}{|c|}{ Factor } \\
\hline & & 1 & 2 & 3 & 4 & 5 & 6 & 7 & 8 & 9 & 10 & 11 & 12 \\
\hline & $\begin{array}{l}\text { networks to find new } \\
\text { job opportunities. }\end{array}$ & & & & & & & & & & & & \\
\hline 11 & $\begin{array}{l}\text { I have built a network } \\
\text { of friendships with } \\
\text { people that can } \\
\text { advance my career. }\end{array}$ & & & & & & & & & & & 0.58 & \\
\hline 42 & $\begin{array}{l}\text { I am comfortable in } \\
\text { uncertain situations. }\end{array}$ & & & & & & & & & & & 0.57 & \\
\hline 19 & $\begin{array}{l}\text { I am generally } \\
\text { satisfied with myself. }\end{array}$ & & & & & & & & & & & & 0.68 \\
\hline
\end{tabular}

Source: Calculated form survey results

The twelfth factor consisted of only one variable and was not subjected to any further analysis. The other eleven factors were labelled as emotional awareness, career resilience, self-development, cultural competence, innovation, perseverance, career self-directedness, reflection, sociability, proactivity, and networking. The Cronbach's alpha coefficient for each of the identified factors in this study is shown in Table 2 below.

\section{Table 2: Reliability results}

\begin{tabular}{|l|l|l|}
\hline ID & Factor & Cronbach's alpha \\
\hline $\mathbf{1}$ & Emotional awareness & 0.85 \\
\hline $\mathbf{2}$ & Career resilience & 0.87 \\
\hline $\mathbf{3}$ & Self-development & 0.89 \\
\hline $\mathbf{4}$ & Cultural competence & 0.86 \\
\hline $\mathbf{5}$ & Innovation & 0.83 \\
\hline $\mathbf{6}$ & Perseverance & 0.84 \\
\hline $\mathbf{7}$ & Career self-directedness & 0.77 \\
\hline
\end{tabular}

Journal of Contemporary Management

DHET accredited

ISSN 1815-7440
Volume 16

2019

Pages 106-139
Page 19 


\begin{tabular}{|l|l|l|}
\hline $\mathbf{8}$ & Reflection & 0.76 \\
\hline $\mathbf{9}$ & Sociability & 0.78 \\
\hline $\mathbf{1 0}$ & Proactivity & 0.72 \\
\hline $\mathbf{1 1}$ & Networking & 0.77 \\
\hline
\end{tabular}

Source: Calculated form survey results

When conducting the Cronbach's alpha coefficient, the reliability of factors 10 (proactivity) and 11 (networking) was below the acceptable threshold value of 0.70 . The Cronbach's alpha for these factors initially was 0.36 and 0.52 respectively. Subsequently, one statement within each factor with a low item-total correlation was removed. This resulted in higher reliability values as reported in Table 2 . The statements that were removed were statement 19, "I am generally satisfied with myself", statement 21 , "I have many good qualities" and statement 42, "I am comfortable in uncertain situations". These statements will be reported on separately. The reliability coefficients reported in Table 2 show acceptable internal consistency (reliability) of the EFA (cut-off point of 0.70 ). In general, the researchers regarded the measuring instrument as reliable for interpreting the results.

\subsubsection{Age effects of self-perceived employability}

Results from the independent t-test (Table 3) and mean scores suggest that Generation $Y$ $(M=4.53, S D=0.91)$ obtained higher mean values than did Generation $X(M=4.70, S D=$ 0.87 ) on the employability attribute self-development; $t(503)=-2.13, p=0.03$. For all the other employability attributes there were no statistical significant differences between Generation X and Generation Y students. 
Table 3: $\quad$ Age effects of self-perceived employability

\begin{tabular}{|l|l|l|l|l|l|}
\hline & \multicolumn{3}{|l|}{$\begin{array}{l}\text { Levenes' test for equality } \\
\text { of variance }\end{array}$} & \multicolumn{2}{l}{ t-test for equality of means } \\
\cline { 2 - 6 } Employability construct & F & Sig. & t & df & Sig. (2-tailed) \\
\hline Emotional awareness & 0.14 & 0.71 & -0.41 & 530 & 0.68 \\
\hline Career resilience & 0.00 & 0.95 & -1.64 & 520 & 0.10 \\
\hline Self-development & 0.89 & 0.35 & -2.12 & 503 & $0.03^{*}$ \\
\hline Cultural competence & 0.43 & 0.51 & -0.25 & 527 & 0.80 \\
\hline Innovation & 2.88 & 0.09 & -1.15 & 493 & 0.25 \\
\hline Perseverance & 0.23 & 0.87 & -0.62 & 516 & 0.53 \\
\hline Career self-directedness & 0.63 & 0.43 & -1.08 & 526 & 0.27 \\
\hline Reflection & 0.07 & 0.79 & -0.90 & 530 & 0.50 \\
\hline Sociability & 0.08 & 0.77 & -1.23 & 532 & 0.22 \\
\hline Proactivity & 0.06 & 0.81 & -0.45 & 531 & 0.65 \\
\hline Networking & 0.00 & 0.96 & -0.76 & 553 & 0.45 \\
\hline
\end{tabular}

Source: Calculated from survey results

The results from the Mann-Whitney $U$ test (see Table 4) analysis revealed a statistically significant difference for the employability attribute of self-satisfaction in favour of Generation $X$ students (mean rank $=252.28, n=249$ ) as compared to Generation $Y$ students (mean rank $=282.57, \mathrm{n}=287) ;(\mathrm{U}=31692.00, \mathrm{z}=-2.33, \mathrm{p}=0.02, \mathrm{r}=0.10)$. 
Table 4: $\quad$ Mann Whitney $U$ test: Differences between Generation $X$ and $Y$

\begin{tabular}{|l|l|l|l|}
\hline & $\begin{array}{l}\text { Question 19 } \\
\text { "I am generally satisfied } \\
\text { with myself." }\end{array}$ & $\begin{array}{l}\text { Question 21 } \\
\text { "I have many good } \\
\text { qualities." }\end{array}$ & $\begin{array}{l}\text { Question 42 } \\
\text { "I am comfortable in } \\
\text { uncertain situations." }\end{array}$ \\
\hline Mann-Whitney U & 31692.00 & 35291.50 & 34199.50 \\
\hline Wilcoxon W & 62817.00 & 76619.50 & 65574.50 \\
\hline Z & -2.33 & -0.34 & -0.89 \\
\hline $\begin{array}{l}\text { Asymp. Sig. } \\
\text { (two-tailed) }\end{array}$ & 0.02 & 0.73 & 0.37 \\
\hline
\end{tabular}

Source: Calculated from survey results

\subsubsection{Gender effects on employability self-perceptions}

Findings from both the independent t-test and Mann Whitney $U$ test did not find any statistically significant difference in employability attribute values relating to gender.

\subsubsection{Ethnicity/race and education level effects on employability self- perceptions}

Results from ANOVA revealed a significant difference by ethnicity/race with regard to the construct career resilience $(F 3,527)=3.88, p=0.01$. A post-hoc test using the Tukey HSD multiple comparison test indicated that white students $(M=4.64, S D=0.97)$ self-perceived to be employable to a greater extent than Indian students $(M=4.59, S D=0.89)$, coloured students $(M=4.48, S D=1.01)$ and black students $(M=4.48, S D=0.82)(p .<.001)$. See Table 5. 
Table 5: Ethnicity/race level effects on employability self-perceptions

\begin{tabular}{|c|c|c|c|c|c|c|}
\hline Construct & & Sum of squares & df & Mean Square & $F$ & Sig. \\
\hline Emotional awareness & $\begin{array}{l}\text { Between groups } \\
\text { Within groups } \\
\text { Total }\end{array}$ & $\begin{array}{l}0.93 \\
372.74 \\
373.67\end{array}$ & $\begin{array}{l}3 \\
537 \\
540\end{array}$ & $\begin{array}{l}0.31 \\
0.69\end{array}$ & 0.45 & 0.72 \\
\hline Career resilience & $\begin{array}{l}\text { Between groups } \\
\text { Within groups } \\
\text { Total }\end{array}$ & $\begin{array}{l}8.82 \\
398.84 \\
407.66\end{array}$ & $\begin{array}{l}3 \\
527 \\
529\end{array}$ & $\begin{array}{l}2.94 \\
0.76\end{array}$ & 3.89 & 0.01 \\
\hline Self-development & $\begin{array}{l}\text { Between groups } \\
\text { Within groups } \\
\text { Total }\end{array}$ & $\begin{array}{l}7.27 \\
414.11 \\
421.37\end{array}$ & $\begin{array}{l}3 \\
526 \\
529\end{array}$ & $\begin{array}{l}2.42 \\
0.79\end{array}$ & 3.08 & 0.03 \\
\hline Cultural competence & $\begin{array}{l}\text { Between groups } \\
\text { Within groups } \\
\text { Total }\end{array}$ & $\begin{array}{l}4.85 \\
515.65 \\
520.51\end{array}$ & $\begin{array}{l}3 \\
534 \\
537\end{array}$ & $\begin{array}{l}1.62 \\
0.97\end{array}$ & 1.68 & 0.17 \\
\hline Innovation & $\begin{array}{l}\text { Between groups } \\
\text { Within groups } \\
\text { Total }\end{array}$ & $\begin{array}{l}4.98 \\
479.36 \\
484.34\end{array}$ & $\begin{array}{l}3 \\
535 \\
538\end{array}$ & $\begin{array}{l}1.66 \\
0.90\end{array}$ & 1.85 & 0.14 \\
\hline Perseverance & $\begin{array}{l}\text { Between groups } \\
\text { Within groups } \\
\text { Total }\end{array}$ & $\begin{array}{l}2.32 \\
341.45 \\
343.76\end{array}$ & $\begin{array}{l}3 \\
522 \\
525\end{array}$ & $\begin{array}{l}0.77 \\
0.65\end{array}$ & 1.18 & 0.32 \\
\hline Reflection & $\begin{array}{l}\text { Between groups } \\
\text { Within groups } \\
\text { Total }\end{array}$ & $\begin{array}{l}3.58 \\
341.45 \\
343.76\end{array}$ & $\begin{array}{l}3 \\
522 \\
525\end{array}$ & $\begin{array}{l}3.56 \\
0.99\end{array}$ & 3.59 & 0.01 \\
\hline Sociability & $\begin{array}{l}\text { Between groups } \\
\text { Within groups } \\
\text { Total }\end{array}$ & $\begin{array}{l}0.67 \\
686.73 \\
687.40\end{array}$ & $\begin{array}{l}3 \\
538 \\
541\end{array}$ & $\begin{array}{l}0.224 \\
1.28\end{array}$ & 0.18 & 0.91 \\
\hline
\end{tabular}

Journal of Contemporary Management

DHET accredited

ISSN 1815-7440

\section{Volume 16}

2019

Pages 106-139
Page 23 


\begin{tabular}{|l|l|l|l|l|l|l|}
\hline Proactivity & Between groups & 0.40 & 3 & 0.14 & 0.19 & 0.91 \\
& Within groups & 389.73 & 538 & 0.72 & & \\
& Total & 390.14 & 541 & & & \\
\hline Networking & Between groups & 4.36 & 3 & 1.44 & 0.80 & 0.50 \\
& Within groups & 975.41 & 540 & 1.81 & & \\
& Total & 979.73 & 543 & & & \\
\hline
\end{tabular}

Source: Calculated form survey results

Similarly, white students self-perceived with higher employability on the attributes of selfdevelopment and career self-directedness compared to other racial groups $(p<.0001)$ (see Table 5). However, Indian students self-reported with higher self-satisfaction compared to other racial groupings. The Kruskal-Wallis test was used to determine whether statistical significant differences exist between race levels with regard to the following: statement 19, "I am generally satisfied with myself", statement 21 , "I have many good qualities" and statement 42, "I am comfortable in uncertain situations". Results are shown in Table 6.

Table 6: Ethnicity effects on self-perceived employability

\begin{tabular}{|l|l|l|l|}
\hline & $\begin{array}{l}\text { Statement 19 } \\
\text { "I am generally satisfied with } \\
\text { myself." }\end{array}$ & $\begin{array}{l}\text { Statement 21 } \\
\text { "I have many good qualities." }\end{array}$ & $\begin{array}{l}\text { Statement 42 } \\
\text { "I am comfortable in } \\
\text { uncertain situations." }\end{array}$ \\
\hline Chi-Square & 12.14 & 1.63 & 0.31 \\
\hline df & 3 & 3 & 3 \\
\hline Asymp (Sig.) & 0.01 & 0.65 & 0.96 \\
\hline
\end{tabular}

Source: Calculated from survey results

Results from Table 6 revealed a statistically significantly difference in statement 19, "I am generally satisfied with myself" across the four cultural groups (Indian, $n=161$, black, $n=$ 228 , coloured, $n=53$ and white, $n=103), x^{2}(3, n=545)=12.14, p=0.01$. The Indian group

Journal of Contemporary Management

DHET accredited

ISSN 1815-7440

\section{Volume 16}

2019

Pages 106-139
Page 24 
had a higher mean rank ( $\mathrm{Md}=288.26$ ) than the other cultural groups, thereby indicating that they tend to agree more with the statement than the other cultural groups. With regard to educational level, no statistical difference was found.

\section{DISCUSSION}

This study sought to determine the employability attributes of undergraduate and postgraduate students under study as well as to how working students within an ODL university self-perceive their employability, taking into account their socio-demographics of age, ethnicity, gender, and qualifications level. By investigating this, the study intended to bring a measure of clarification to the construct of employability and its application in the current knowledge-driven business context.

With regard to the first objective, the researchers found the following eleven constructs to be the employability attributes of students under study: emotional awareness, career resilience, self-development, cultural competence, innovation, perseverance, career self-directedness, reflection, proactivity and networking.

The researchers found a statistical difference between age and certain employability attribute constructs. Specifically, it was found that Generation X students self-perceived as higher on self-development needs than Generation $Y$ students. This finding is contrary to findings by Oosthuizen, Coetzee and Mntonintshi (2014), who found that different age groups ( $\leq 25$ years and $26-45$ years) did not differ significantly regarding their employability attributes. However, Van Rooy et al. (2005) found a positive relationship between age and employability.

According to Instant Impact (2014), Generation Y students place greater value on their own personal development, suggesting continued learning. In fact, personal development was the most important factor when choosing a job for Generation $Y$ students. It was further found that Generation $Y$ students are more satisfied with themselves than Generation $X$ 
students. The results of the latter finding suggest that Generation $Y$ students are more content with themselves. This is in line with the characteristics of the Generation $\mathrm{Y}$ cohort who are seen as confident (Benckendorff \& Moscardo 2013). Jackson (2012) posits that overconfidence in personal ability is commonly associated with Generation $\mathrm{Y}$ graduates. In a study by Solnet, Kralj and Kandampully (2012), they found that the Generation Y cohort consider themselves more employable than their non-generation $\mathrm{Y}$ counterparts.

The researchers found no significant difference between gender and employability selfperceptions. This finding confirms findings of Potgieter (2012), but contradicts findings of Bezuidenhout (2011), Clarke (2008) and Harvey (2000). The results from this study are also contrary to findings by Quenani, MacDougall and Sexton (2014) where it was found that male students have $50 \%$ more confidence in their employability skillset compared to female students. However, findings of this study support the findings by Koloba (2015), Karli (2016), Rothwell, et al. (2009) as well as Rothwell and Arnold (2007), who found no direct relationship between gender and any type of self-perceived employability. This result is encouraging, given the fact that females have more often lagged behind their male counterparts in terms of employment (Koloba 2015:135).

The researchers found a statistical difference between ethnicity and certain employability attribute constructs. In this study, white students self-rated higher on the employability attributes of career resilience and self-development. It was also found that Indian students self-reported with higher self-satisfaction compared to other racial groupings. Rothwell et al. (2009) found no significant difference between self-perceived employability and ethnicity, yet contrary to these findings; Croucher et al. (2018) found that ethnic group effects on perceived employability do exist, although minimal. It was also found that there is a difference in career self-directedness between black and white students.

In a study on Arabic undergraduate students, Khasawneh (2010) found that ethnic-gender expectations were perceived by students as having low levels of influence on their career

Journal of Contemporary Management

DHET accredited

ISSN 1815-7440
Volume 16

2019

Pages 106-139
Page 26 
planning. Reio (2004) reported similar findings from his studies at a major university in the mid-Atlantic region of the United States. However, our findings contradict those by Fisher and Stafford (2002), who found that there was no significant difference among AfricanAmerican, Hispanic, and Anglo-American students on career resilience.

Findings of the present study are likely explained by the fact that these students are able to adapt to changing situations and have the self-confidence to master the challenges presented by a situation or event (Potgieter 2012). Individuals who possess career resilience have a higher sense of control over their future and the direction their careers will take (Schreuder \& Coetzee 2011). Hence, the white students' self-perceived high levels of career resilience and development suggest that they feel in control over the direction their careers will take. Nevertheless, it could possibly also be attributed to the historic advantage of white students accessing and retaining employment (Oluwajodu, Blaauw, Greyling \& Kleynhans 2015). Then again, the findings in the current study about Indian students' high level of selfsatisfaction suggest that these working students are happy with their studies in an ODL environment. Their high satisfaction level could also be interpreted as working students who are confident that they will accomplish their career goals through their own development efforts in an ODL environment.

From this study, it is clear that educational level does not have an effect on self-perceived employability. This is contrary to findings from Karli (2016), who found a significant difference in employability perceptions based on educational level. Findings of this study, however, support the findings from Koloba (2015) who found no statistically significant difference in terms of level of study and perceived employability. It is therefore evident that, regardless of year of study, students are equally confident about their employability. 


\section{STUDY LIMITATIONS, CONTRIBUTIONS AND RECOMMEN- DATIONS}

This was a cross-sectional, exploratory study and no statements about causation can be imputed. In addition, the study relied on self-report measures that carry the limitation that the data used are self-reported and reliant on participant self-perceptions. Another limitation is that only $16.5 \%$ of the participants were black. This does not give a clear picture of this population group's view concerning their employability. Moreover, we did not disaggregate for analysis the data for those with employment and those unemployed at the time of study. Considering that environmental factors are important in understanding employability, future studies should focus on the differences between those that are employed and those that are unemployed.

Hence, the findings of the current study suggest that within the current labour market, employers need a better understanding of their role in employability in order to provide all students with the necessary skills to assess their employability attributes related to the needs of the labour market. Additionally, HEls are also required to gain a better understanding of their role in employability in order to provide all students with opportunities to develop their skills and abilities to become more self-directed in their learning and to take control of their own careers, especially within the black and coloured ethnicity groups. Therefore, the researchers recommend a need for more qualitative research related to selfreport studies to gain more in-depth experience in terms of employability attributes of adult learners. The researchers furthermore recommend intervention methods to create social learning opportunities between all the different ethnicity and age groups. Such opportunities need to create prospects for these groups to learn from one another. A typical qualitative research study could enable these groups to tell more in-depth narratives about their career resilience, career development and satisfaction levels to flourish within the current labour market.

Journal of Contemporary Management

DHET accredited

ISSN 1815-7440
Volume 16

2019

Pages 106-139
Page 28 
Lastly, it is recommended that HR professionals involved in organisational training design programmes that are innovative and sufficiently diverse to connect with all student cohorts. Training programmes should be designed in such a manner that they utilise the expertise of both academics and career development practitioners, thereby empowering more explicit understanding of learning outcomes by academics, students and business audiences.

\section{CONCLUSION}

The study revealed that the self-perceived employability attributes of self-development and self-directedness differ by ethnicity and age. Specifically, Generation X students selfperceived higher on the employability attribute self-development, while Generation $Y$ selfperceived higher on the employability attribute self-satisfaction. A significant difference by ethnicity/race with regard to the employability construct career resilience was found, where white students self-perceived to be employable to a greater extent than the other ethnic groups. However, a turbulent changing workplace towards a fourth industrial revolution requires from both university programmes and human resource development programmes to create a level of stability and a calling for adult learners to become aware and assess their own levels of self-directedness, resilience and fulfilment for self-development career opportunities. Therefore, graduate employability programmes emphasising individual skills and knowledge need to be complemented by targeted geographical and industry development, continuing (lifelong) education programmes beyond university and social inclusion initiatives in order to be effective.

\section{ACKNOWLEDGEMENT}

The authors would like to thank Dr Marthi Pohl for the assistance with the statistical analysis as well as the two anonymous reviewers for their valuable inputs to improve the quality of the article. 


\section{REFERENCES}

ATTRI AK. 2012. Distance education: Problems and solutions. International Journal of Behavioral Social and Movement Sciences 1(4):42-58.

BAKER G \& HENSON D. 2010. Promoting employability skills development in a research-intensive university. Education + Training 52(1):62-75.

BARTHORPE S \& HALL M. 2000. A collaborative approach to placement preparation and career planning for university students: a case study. Journal of Vocational Education and Training 52 (2):165-175.

BENCKENDORFF P \& MOSCARDO G. 2013. Generational cohorts and ecotourism. In Ballantyne, Roy \& Packer, Jan. Eds. International Handbook on Ecotourism. Cheltenham, UK: Edward Elgar Publishing. (pp 135154.)

BENNETT D. 2016. Enacting strategies for graduate employability. How universities can best support students to develop generic skills. [Internet:https://melbourne-

cshe.unimelb.edu.aul_data/assets/pdf_file/0011/1874774/SP13-3258_Curtin_Bennett_Graduate-

Employability_Final-Report_Part-A_20163.pdf; downloaded on 04 December 2018.]

BEJTKOVSKÝ J. 2016. The current generations: The baby boomers, $X, Y$ and $Z$ in the context of human capital management of the $21^{\text {st }}$ Century in selected corporations in the Czech Republic. Littera Scripta 9(2):25-45 [Internet:http://journals.vstecb.cz/wp-content/uploads/2017/02/The-Current-Generations-The-Baby-Boomers.pdf, downloaded on 05 December 2018.]

BEZUIDENHOUT M \& COETZEE M. 2010. Preliminary exploratory factor analysis: Student employability scale. University of South Africa. University of South Africa. (Unpublished research report.)

BEZUIDENHOUT M. 2011. The development and evaluation of a measure of graduate employability in the context of the new world of work. University of Pretoria, South Africa. (Masters' dissertation.)

BIEMANN TT, ZACHER, H \& FELDMAN A. 2012. Career patterns: A twenty-year panel study. Journal of Vocational Behaviour 81(2):159-170.

BODEN R \& NEDEVA M. 2010. Employing discourse: Universities and graduate 'employability'. Journal of Education Policy 25(1):37-54. [Internet:https://doi/org/10.1080/0268093093349489; downloaded 16 March 2018.] BRISCOE JP \& HALL DT. 2006. The interplay of boundaryless and protean careers: combinations and implications. Journal of Vocational Behaviour 69(1):4-18.

BRISCOE JP, HALL DT \& DEMUTH RL. 2006. Protean and boundaryless careers: an empirical exploration. Journal of Vocational Behaviour 69(1):30-47.

BOTHA JA. 2014. The relationship between adult learner self-directedness and employability attributes - an open distance learning perspective. (Masters' dissertation.)

BOTHA J, COETZEE M \& COETZEE M. 2015. Exploring adult learners' self-directedness in relation to their employability attributes in open distance learning, Journal of Psychology in Africa 25(1):65-72.

BUSSIN M. 2012. The remuneration handbook for Africa. $2^{\text {nd }}$ Ed. Randburg: Knowres Publishing.

Journal of Contemporary Management

DHET accredited

ISSN 1815-7440
Volume 16

2019

Pages 106-139
Page 30 
CENNAMO L \& GARDNER D. 2008. Generational differences in work values, outcomes and personorganisation values fit. Journal of Managerial Psychology 23:891-906.

CLARKE M. 2008. Understanding and managing employability in changing career contexts. Journal of European Industrial Training 32 (4): 258-284.

[Internet:https://www.emeraldinsight.com/doi/full/10.1108/03090590810871379;downloaded on 21 May 2017.]

COETZEE M. 2010. Preliminary factor analysis of the employability attributes scale. Pretoria: University of South Africa. (Unpublished research report.)

COETZEE M. 2012. A framework for developing student graduateness and employability in Economic and Management Sciences at the University of South Africa. In Coetzee M, Botha J, Neil E, Holtzhauzen NN \& Nienaber NN. Eds. Developing student graduateness \& employability: Issues, provocations, theory and practical guidelines. Randburg: Knowres Publishing (Pty) Ltd. (pp 119-152.)

COETZEE M \& POTGIETER IL. 2014. The relation of cognitive learning strategies to psychosocial employability attributes among black adult learners in the economic and management sciences field. SA Journal of Human Resource Management 12 (1). (Art. \#554, 12 pages).

[Internet:https://sajhrm.co.za/index.php/sajhrm/article/view/554/754; downloaded on 01 April 2016.]

COETZEE M \& SCHREUDER AMG. 2008. A multi-cultural investigation of students' career anchors at a South African higher education institution. SA Journal of Labour Relations 32(2):1-21.

CROUCHER R, RAMAKRISHNAN S, RIZOV M \& BENZINGER D. 2018. Perceptions of employability among London's low-paid: 'Self-determination" or ethnicity? Economic and Industrial Democracy 39(1):109-130. [Internet:https://journals.sagepub.com/doi/pdf/10.1177/0143831X15609672; downloaded on 06 May 2017.]

DE GUZMAN AB \& CHOI KO. 2013. The relationship of employability skills to career adaptability among technical school students. Journal of Vocational Behaviour 81:199-207.

[Internet:http://dx.doi.org/10.1016/j.jvb.2013.01.009; downloaded on 12 March 2018.]

FISHER TA \& STAFFORD ME. 2002. The Impact of Career and Ethnic Influences on Career Resilience. ERIC research paper (April 2002). [Internet:www.eric.ed.gov/?id=ED442959; downloaded on 02 June 2016.]

FRY H, KETTERIDGE S \& MARSHALL S. 2009. A handbook for teaching and learning in higher education. $3^{\text {rd }}$

Ed. [Internet:https://www.sun.ac.za/english/learning-

teaching/ct//Documents/A\%2OHandbook\%20for\%20Teaching\%20and\%2OLearning\%20in\%20Higher\%20Educati on\%20Enhancing\%20academic\%20and\%20Practice.pdf; downloaded on 04 December 2018.]

HANKIN H. 2005. The new workforce: Five sweeping trends that will shape your company's future. (New York, MY: AMACOM.)

HARVEY L. 2000. New Realities: The relationship between higher education and employment. Tertiary Education and Management 6:3-17.

HILLAGE J \& POLLARD E. 1998. Employability: Developing a Framework for Policy Analysis. Department for Education and Employment. London.

Journal of Contemporary Management

DHET accredited

ISSN 1815-7440

\section{Volume 16}

2019

Pages 106-139
Page 31 
INSTANT IMPACT. 2014. Y so self-entitled? Generation Y's attitude to the working world. [Internet:www.princetonone.com/news/PrincetonOne\%20White\%20Paper2.pdf; downloaded on 12 February 2015.]

JACKSON D. 2012. Business undergraduates' perceptions of their capabilities in employability skills. Implications for industry and higher education. Industry and Higher Education 26(5):345-356.

JACKSON D. 2014. Employability skills development in work integrated learning: Barriers and best practice. Edith Cowan University. Research online (1):1-18.

JONCK P, VAN DER WALT F \& SOBAYENI NC. 2017. A generational perspective on work values in a South African sample. SA Journal of Industrial Psychology 43. [Internet:http://www.scielo.org.za/pdf/sajip/v43n1/01.pdf; downloaded on 05 December 2018.]

KARLI U. 2016. Adaption and validation of self-perceived employability scale: An analysis of sports department students and graduates. Educational Research and Reviews 11 (8):848-859.

[Internet:https://files.eric.ed.gov/fulltext/EJ1099997.pdf; downloaded on 17 January 2019.]

KOLOBA HA. 2015. The relationship between perceived employability and intention for self-employment among university students. (Doctoral thesis.)

KHASAWNEH S. 2010. Factors influencing the Career Planning and Development of University Students in Jordan. Australian Journal of Career Development 19(2):41-48.

[Internet:http://journals.sagepub.com/doi/abs/10.1177/103841621001900206\#articleCitationDownloadContainer; downloaded on 05 March 2016.]

KUPPERSCHMIDT BR. 2000. Multigenerational Employees: Strategies for Effective Management. The Health Care Manager 19(1):65-76.

LITTLE B. 2006. Employability and work-based learning. York: Higher Education Academy.

LITTLE BM. 2011. Employability for the workers - what does this mean? Education and Training 53(1):57-66. [Internet:http://oro.open.ac.uk/28012/; downloaded on 21 November 2016.]

LOURENS E \& FOURIE-MALHERBE M. 2016. The employability of higher education graduates: are qualifications enough? [Internet:http://www.econ3x3.org/sites/default/files/articles/Lourens\%20\%20FourieMalherbe $\% 202016 \% 20$ Employability\%20and\%20HE\%20graduate\%20identity\%2OFINAL.pdf; downloaded on 15 March 2018.]

MASON G, WILLIAMS G, CRANMER S \& GUILE D. 2003. How Much Does Higher Education Enhance the Employability of Graduates? University of London, London. Report to the Higher Education Funding Council for England, Institute of Education.

McGUIGAN CH. 2010. Generation and career concern: their impact on perceptions of employability and job insecurity in a changing employment context (Masters' dissertation.)

MOOLMAN H. 2013. The Delphi technique as a competency modelling method. Barcelona, Spain: EDULEARN ( $5^{\text {th }}$ International conference on Education and New Learning Technologies. (1-3 July 2013.)

Journal of Contemporary Management

DHET accredited

ISSN 1815-7440
Volume 16

2019

Pages 106-139

Page 32 
MOREAU M \& LEATHWOOD C. 2006. Graduates' employment and the discourse of employability: a critical analysis. Journal of Education and Work 19(4):305-324.

NDZUBE F. 2013. The relationship between career anchors and employability. Pretoria: University of South Africa. (Unpublished dissertation.)

NIELSEN J. 1999. Employability and workability among Danish employees. Experimental Aging Research 25:393-397.

ORGANISATION FOR ECONOMIC CO-OPERATION AND DEVELOPMENT (OECD). 2016. Enhancing employability. Report prepared for the G20 Employment Working Group.

[Internet:https://www.oecd.org/employment/emp/Enhancing-Employability-G20-Report-2016.pdf, downloaded on 10 September 2018.]

OLIVIER B. 2015. Redefining graduate employability and work-integrated learning" Proposals for effective higher education in disrupted economies. Journal of Teaching and Learning for Graduate Employability 16(1):55-65. [Internet:https://static1.squarespace.com/static/5b8c7e43b98a785d39aab231/t/5ba47774e4966b2bc5d0d404/15 37505142899/Oliver+2015+\%281\%29.pdf; downloaded on 18 January 2019.]

OLUWAJODU F, BLAAUW D, GREYLING L \& KLEYNHANS EWERT PJ. 2015. Graduate unemployment in South Africa: Perspectives from the banking sector. South African Journal of Human Resource Management 13(1). Art. \# 656, 9 pages. [Internet:http://dx.doi.org/10.4102/sajhrm.v131i1.656; downloaded on 06 May 2017.]

OOSTHUIZEN RM, COETZEE M \& MNTONINTSHI F. 2014. Investigating the relationship between employees' career anchors and their psychosocial employability attributes in a financial company. South African Journal of Human Resource Management 12(1), Art. \#650. 10 pages. [Internet:https://dz.doi.org.10.4102/sajhrm.v12i1.650; downloaded on 17 January 2019.]

PAADI K. 2014. Perceptions on employability skills necessary to enhance human resource management graduates prospectus of securing relevant place in the labour market. European Scientific Journal. (pp 129-143.)

PAUW K, OOSTHUIZEN M \& VAN DER WESTHUIZEN C. 2008. Graduate unemployment in the face of skills shortages: A labour market paradox. South African Journal of Economics 76(1):45-57.

PEGG A, WALDOCK J, HENDY-ISAAC S \& LAWTON R. 2012. Pedagogy for employability. The Higher Education Academy. [Internet:https://www.heacademy.ac.uk/workstreams-research/themes/employability; downloaded on 05 March 2018.]

POTGIETER IL. 2012. The development of a career meta-competency model for sustained employability. Pretoria, University of South Africa. (Doctoral thesis.)

POTGIETER IL \& COETZEE M. 2013. Employability attributes and personality preferences of postgraduate business management students. South African Journal of Industrial Psychology 39(1):1-10.

PROKOU E. 2008. The emphasis on employability and the changing role of the university in Europe. Higher Education in Europe 33(4):387-394.

Journal of Contemporary Management

DHET accredited

ISSN 1815-7440
Volume 16

2019

Pages 106-139
Page 33 
QUENANI E, MACDOUGALL N \& SEXTON C. 2014. An empirical study of self-perceived employability: Improving the prospects for student employment success in an uncertain environment. Active Learning in Higher Education 15(3):199-2013. (DOI:10.1177/14697874544875.)

REIO TG. 2004. Prior knowledge, self-directed learning readiness and curiosity. Antecedents to classroom learning performance. International Journal of Self-Directed Learning 1(1):18-25.

ROTHWELL A \& ARNOLD J. 2007. Self-perceived employability: development and validation of a scale. Personnel Review 36(1):23-41.

ROTHWELL A, JEWELL S \& HARDIE M. 2009. Self-perceived Employability: Investigating the Response of Post-Graduate Students. Journal of Vocational Behavior 75(2):152-161.

SCHREUDER AMG \& COETZEE M. 2011. Careers: An organisational perspective. Cape Town: Juta.

SHEAHAN P. 2005. Generation Y: Thriving and surviving with generation $Y$ at work. Victoria: Hardie Grant Books.

SOLNET D, KRALJ A \& KANDAMPULLY J. 2012. Generation Y Employees: An Examination of Work Attitude Differences. Journal of Applied Management and Entrepreneurship 17(3):36-54.

STOKES CL. 2013. A case study Understanding Employability through the lens of Human Resource Executives. University of South Florida. [Internet: http://scholarcommons.usf.edu/etd/4779/; downloaded on 13 March 2018.] (PhD thesis.)

SULLIVAN SE \& BARUCH Y. 2009. Advances in career theory and research: a critical review and agenda for future exploration. Journal of Management 35(6):1542-1571.

ŚWIGOǸ M. 2016. Self-perceived employability of students of international relations of University of Warmia and Muzury in Poland. International Journal of Humanities and Social Sciences 12(11):3610-3615.

THINDWA FS. 2016. Factors influencing employability of technical education graduates in Malawi. University of the Witwatersrand. (Masters' dissertation.)

TUMUTI DW, MULE LW, GECAGA M \& MANGURIU DG. 2013. Enhancing Graduate Employability through Community Engagement: A Case Study of Student's Community Service at Kenyatta University. Journal of Administrative Sciences and Policy Studies 1(1):1-14.

VAN ROOY D, ALONSO A \& VISWESVARAN C. 2005. Group differences in emotional intelligence scores: theoretical and practical implications. Personality and Individual Differences 38:689-700.

VAN DER HEIJDEN B. 2000. Prerequisites to guarantee life-long employability. Personnel Review 31:44-61. YORKE M. 2006. Employability in higher education: what it is - what it is not. Learning and Employability Series, Higher Education Academy.

ZIKMUND WG, BABIN BJ, CARR JC, CARR J \& GRIFFIN M. 2013. Business Research Methods. $9^{\text {th }}$ ed. Stamford, CT: Cengage Learning.

Journal of Contemporary Management

DHET accredited

ISSN 1815-7440
Volume 16

2019

Pages 106-139
Page 34 